\title{
Vegetative propagation of Rhaphiodon echinus Schauer (Lamiaceae): effects of the period of cutting in rooting, cuttings arrangement and IBA concentrations for seedlings production ${ }^{(1)}$
}

\author{
EUVALDO DE SOUSA COSTA JUNIOR ${ }^{(2)}$, MAYARA SUZANNE DE MELO BARBOSA(3), \\ CÂNDIDA MARIA ANJOS DA SILVA(3), RAÍRA CARINE SANTANA DA SILVA ${ }^{(4)}$, LUCIA HELENA PIEDADE KIILL ${ }^{(4)}$, \\ MÁRKILLA ZUNETE BECKMANN-CAVALCANTE ${ }^{(3)^{*}}$
}

\begin{abstract}
One of the tendencies in the floriculture sector, whether in modern landscaping or floral art, is related to the insertion of innovations in the sector, mainly of native origin. For this it is necessary to establish strategies that favor the introduction of these materials. Among the species that present ornamental potential, Rhaphiodon echinus Schauer has been outstanding for groundcover; however it is necessary to establish the proper propagation protocol for the species. In this sense, the objective was to evaluate the vegetative propagation process of this species considering the period of cutting in rooting, cuttings arrangement and IBA concentrations for seedlings production. The experiment was carried out in a sub-split plots scheme with the period of cutting in rooting in the plots (30 and 60 days), the cuttings arrangement (horizontal and vertical) in the subplots and the IBA concentrations $(0 ; 1,000$; 2,000 and 4,000 ppm) in sub-subplots. The following variables were evaluated: survival cuttings, percentage of rooted cuttings, number of sprouts per cuttings, average length of the largest root, root volume, shoot dry biomass and root dry biomass. There was a significant interaction between the period of cutting in rooting and the cuttings arrangement for survival cuttings and rooted cuttings; between the period of cutting in rooting and the concentration of IBA for shoot dry and between the cuttings arrangement and concentration and IBA for the percentage of rooted cuttings, number of sprouts per cuttings and root dry biomass. For average length of the largest root and root volume there was a significant effect for period of cutting in rooting and IBA concentrations individually. The period of cutting in rooting of 30 days is the most suitable for rooting the cuttings. In relation of the cuttings arrangement the most indicated is vertical. Finally, the concentration of 1,000 ppm of IBA can be indicated for the propagation of R. echinus by the cutting process.
\end{abstract}

Keywords: Lamiaceae, caatinga biome, floriculture, rooting ability.

\section{RESUMO}

Propagação vegetativa de Rhaphiodon echinus Schauer (Lamiaceae): efeitos do período de estaquia no enraizamento, disposição de estacas e concentrações de AIB para produção de mudas

Uma das tendências no setor da floricultura seja no paisagismo moderno ou na arte floral, está relacionada à inserção de novas espécies com potencial ornamental, principalmente de procedência nativa. Para isso, faz-se necessário estudar estratégias que favoreçam a introdução desses materiais. A espécie Rhaphiodon echinus Schauer é nativa e tem se destacado como forração, existindo a necessidade de estabelecer um protocolo de propagação adequado. Neste sentido, objetivou-se avaliar o processo de propagação vegetativa desta espécie considerando-se o período de estaquia no enraizamento, a disposição das estacas e concentrações de AIB para a produção de mudas. O experiemento foi instalado em esquema de parcelas sub subdivididas, avaliando-se o período de estaquia no enraizamento nas parcelas (30 e 60 dias), a disposição das estacas no substrato (horizontal ou vertical) nas subparcelas e as concentrações de AIB (0, 1.000, 2.000 e 4.000 ppm) nas sub subparcelas. Foi avaliado: sobrevivência de estacas, porcentagem de estacas enraizadas, número de brotos por estacas, comprimento médio da maior raiz, volume de raízes, biomassa seca da parte aérea e biomassa seca da raiz. Ocorreu interação significativa entre período de estaquia no enraizamento e disposição das estacas no substrato para as variáveis sobrevivência de estacas e estacas enraizadas; entre o período de estaquia no enraizamento e concentração de AIB para biomassa seca da parte aérea e, entre disposição de estacas e concentração e AIB para porcentagem de estacas enraizadas, número de brotos por estacas e biomassa seca da raiz. Para o comprimento médio da maior raiz e volume radicular ocorreram efeitos significativos para a interação período de indução das raízes e concentrações de AIB. O período de estaquia no enraizamento de 30 dias e a disposição vertical da estaca no substrato são os mais indicados no processo de propagação. Por fim, a concentração de 1.000 ppm de AIB pode ser indicada para a propagação de $R$. echinus pelo processo de estaquia.

Palavras-chave: Lamiaceae, bioma caatinga, floricultura, capacidade de enraizamento

DOI: http://dx.doi.org/10.14295/oh.v24i3.1232

(1) Received in 01/06/2018 and accepted in 05/09/2018

(2) Universidade Federal do Piauí, Campus Profa. Cinobelina Elvas, Bom Jesus-PI, Brazil.

(3) Universidade Federal do Vale do São Francisco, Agronomic Engineering Course, Petrolina-PE, Brazil. *Corresponding author: markilla.beckmann@ univasf.edu.br

${ }^{(4)}$ Embrapa Semiárido, Petrolina-PE, Brazil.

Licensed by CC BY 4.0 


\section{INTRODUCTION}

The Brazilian floriculture works to introduce novelties in the market due to the demand of consumers looking for different products. So, prospecting native plants that present ornamental potential, both for landscaping and for floral art have been carried out (STUMPF et al., 2009; DRAGOVIC, 2015; BECKMANN-CAVALCANTE et al., 2017a; 2017b). However, not all prospected species are eligible to be introduced immediately on the market, and there is a need for research on breeding programs, establishment of propagation protocols and cropping systems (CARDOSO, 2013).

Brazil has the most abundant flora in the world and in the Caatinga biome can be found around 5.000 plant species, among which 380 are endemic (FORZZA et al., 2012; SIQUEIRA FILHO, 2012). In a study realized by Beckmann-Cavalcante et al. (2017a) were identified 21 species of the Caatinga with herbaceous habit and potential for landscaping. Among these species, it was prospected Rhaphiodon echinus Schauer (Lamiaceae), popularly known as "beton" or "false mint". Beckmann-Cavalcante et al. (2017b) highlighted that this species can be used for the purpose of groundcover, due to the visibility of its ornamental structures and rapid filling of space of the places where they were characterized.

Rhaphiodon echinus is herbaceous and considered a creeping plant, with complete leaves, being arranged opposite each other. The flowers are small, tapered, violet color and are gathered in dense axillary glomeruli containing an average of 20-35 buds (DIAS and KIILL, 2007). The species can be easily identified in the field by the fruits arranged in globular and spinescent glomeruli that carry the diaspores. Naturally it is propagated by seeds; however, the manual removal of the seeds is difficult by the presence of the spinescent fruit (MOREIRA and BRAGANÇA, 2011).

In this context, vegetative propagation by cutting can be an option, because it presents simplicity, speed and low cost in its execution and, being intensively used for propagation of ornamental plants. This is due to the large number of seedlings obtained, the use of a small number of matrices, a reduced area, and the multiplication of genotypes of interest with great uniformity (HARTMANN et al., 2011). Despite that, the viability of the commercial propagation of cuttings depends on the rooting ability of each species, on the quality of the root system formed and the establishment of the seedlings in the field (NEVES et al., 2006).

Nevertheless, even if certain species exhibit good natural rooting ability, the application of synthetic auxins may provide an increase in rooting percentage. The use of plant regulators from auxin class has the purpose of inducing the process of adventitious root formation, increasing the percentage of rooted cuttings, the number and quality of roots formed (TAIZ and ZEIGER, 2013). The most widely used synthetic auxin source for this purpose is 3-Indole Butyric Acid (IBA) as it is stable and immune to biological degradation. However, the results may vary according to the species and / or cultivar, type of cuttings, time of year, concentration, application form and environmental conditions (OINAM et al., 2011; AMARAL et al., 2012; BECKMANN-CAVALCANTE et al., 2014).

Considering the potential use of $R$. echinus, the objective of this study was to evaluate the vegetative propagation process in function of the period of cutting in rooting, cuttings arrangement and IBA concentrations for seedlings production

\section{MATERIAL AND METHODS}

The experiment was conducted from May to July 2017 at the geographic coordinates of $09^{\circ} 21^{\prime} \mathrm{S}, 40^{\circ} 34^{\prime} \mathrm{W}$ and $375 \mathrm{~m}$ altitude. According to Köppen classification, the region presents Bsh climate (dry, semi-arid and with low latitude and altitude) (ALVARES et al., 2014).

Cuttings were collected in the middle of the creeping stem and performed early in the morning. The cuttings came from natural plants population (Figure 1A) conducted without specific cultural treatments as fertilization, irrigation, pruning and pest and disease control. After the cutting of the stem, they were taken to the laboratory for cuttings standardization, with an average length of $3 \pm 1 \mathrm{~cm}$ and a definitive pair of leaves, being cut in a bevel.

The application of IBA concentrations was performed as powder (Figure $1 \mathrm{~B}$ and $1 \mathrm{C}$ ) before the cutting in the trays, following the methodology described by Hartmann et al. (2011). The cuttings were arranged vertically and horizontally in polystyrene trays with 128 cells containing vermiculite with medium granulometry as substrate. The cuttings were vertically arranged in the substrate to a depth of $1.5 \mathrm{~cm}$ or completely covered horizontally in vermiculite to a depth of $0.5 \mathrm{~cm}$. The trays were suspended on a bench with a height of $1 \mathrm{~m}$ from the soil and were planted with $50 \%$ shading, and irrigation was carried out daily with a manual pressurized sprayer. During the period of conduction of the experiment, the climatic data regarding temperature, relative humidity and precipitation were monitored daily, with a mean of $25.6{ }^{\circ} \mathrm{C}, 61.50 \%$ and $5.8 \mathrm{~mm}$, respectively. 

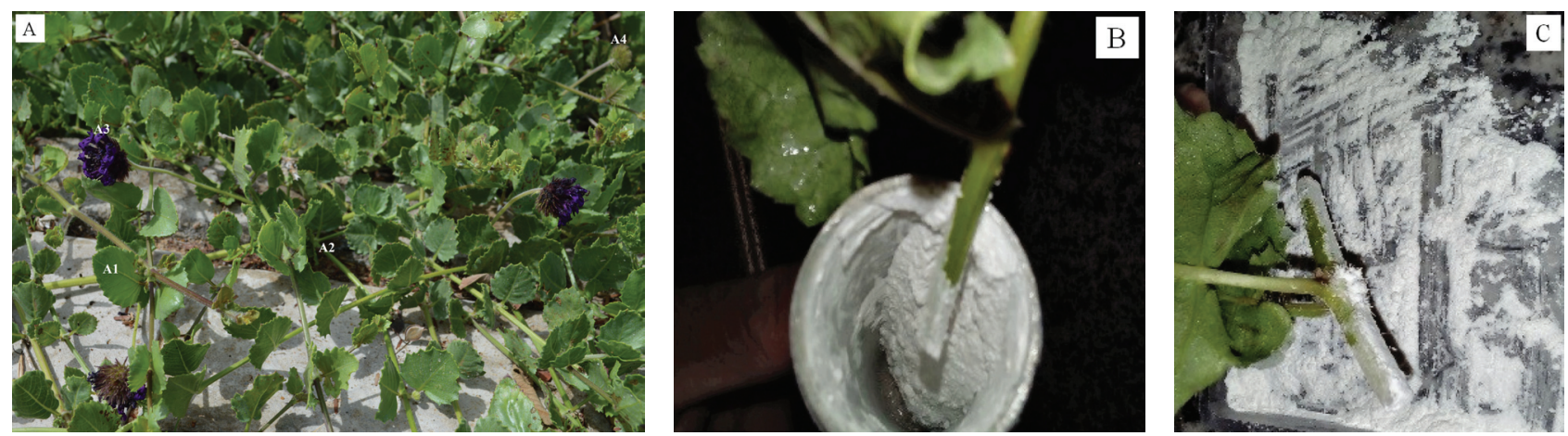

Figure 1. General aspects of Rhaphiodon echinus Schauer: (A) plant in the field, showing leaves (A1), creeping stem (A2), flowers (A3) and fruits (A4); (B) vertical arrangement of cuttings with IBA; (C) horizontal arrangement of cutting with IBA.

The experiment was carried out in a split-split-plot design with the period of cutting in rooting in the whole plot (30 and 60 days), the cuttings arrangement (horizontal and vertical) in the split-plot and the IBA concentrations $(0 ; 1,000 ; 2,000$ and 4,000 ppm) in split-split-plot. Four replicates and eight cuttings were used per repetition, making a total of 512 cuttings.

At 30 and 60 days after cutting, the evaluation of the experiment was performed taking into account the survival cuttings (SC, given by the count of live cuttings by total cuttings per repetition, in percentage), percentage of rooted cuttings (PRC, in relation to the total of cuttings of the repetition, in percentage), number of sprouts per cuttings (NSC, of live cuttings), average length of the largest root (LLR, $\mathrm{mm})$, root volume $\left(\mathrm{RV}, \mathrm{mm}^{3}\right)$, shoot dry biomass (SDB, g) and root dry biomass (RDB, g). To obtain the dried masses of the shoot and root, the respective parts were separated and dried in an oven at $70{ }^{\circ} \mathrm{C}$ with forced circulation until reaching a constant mass and then weighed. For LLR and RV, the roots were conditioned in plastic bags containing $70 \%$ alcohol and stored at $\pm 4{ }^{\circ} \mathrm{C}$. Subsequently, they were analyzed in the software "Delta-T Scan", as recommended by Kirchhof and Pendar (1993).

The data of SC and PRC were transformed by arc sine $\mathrm{x} 100^{-1}$, and for NSC the transformation $\mathrm{x}+\mathrm{k}$ was used to meet the basic assumptions of the statistics. Data were submitted to analysis of variance by the "F" test to diagnose a significant effect; the period of cutting in rooting and the arrangement of cuttings were compared by the Tukey test, while the AIB concentrations were submitted to quantitative simple regression analysis according to recommendations of Ferreira (2000), using the ASSISTAT version 7.7 program (SILVA, 2016) and SigmaPlot ${ }^{\circledR}$ version 12 (SYSTAT SOFTWARE Inc, 2011), respectively.

\section{RESULTS AND DISCUSSION}

The results of the analysis of variance showed significant effect for the interaction between the period of cutting in rooting versus cuttings arrangement for survival cuttings (SC) and percentage of rooted cuttings (PRC). For the interaction of period of cutting in rooting versus IBA concentrations, a significant effect was observed for shoot dry biomass (SDB). In relation to cuttings arrangement $\mathrm{x}$ IBA concentrations, a significant effect was observed for percentage of root cuttings (PRC), number of sprouts per cuttings (NSC) and root dry biomass (RDB) (Table 1).

Considering the period of cutting in rooting, there was a significant effect for SC, average length of the largest root (LLR) and root volume (RV). Regarding the cuttings arrangement, there was a significant effect for SC, NSC and RV. For IBA concentrations, a significant effect was observed for PRC, NSC, LLR, RV and SDB (Table 1). 


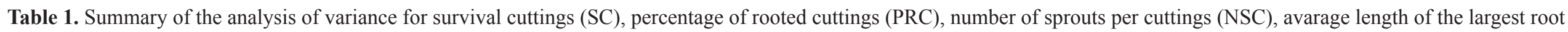

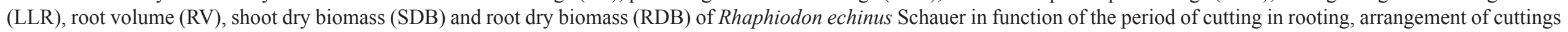
and IBA concentrations.

\begin{tabular}{|c|c|c|c|c|c|c|c|}
\hline Source of variation & SC (\%) & PRC (\%) & NSC & $\operatorname{LLR}(\mathbf{m m})$ & $\mathbf{R V}\left(\mathbf{m m}^{3}\right)$ & SDB (g) & RDB (g) \\
\hline $\begin{array}{l}\text { Period of cutting in rooting } \\
\qquad(\mathrm{PCR})\end{array}$ & $24.83 *$ & $6.03 \mathrm{~ns}$ & $7.70 \mathrm{~ns}$ & $191.83 * *$ & $14.44 *$ & $0.77 \mathrm{~ns}$ & $0.29 \mathrm{~ns}$ \\
\hline 30 days & $61.61 \mathrm{a}$ & $44.05 \mathrm{a}$ & $1.20 \mathrm{~ns}$ & $121.61 \mathrm{~b}$ & $152.90 \mathrm{~b}$ & $0.44 \mathrm{a}$ & $0.26 \mathrm{a}$ \\
\hline 60 days & $47.86 \mathrm{~b}$ & $40.51 \mathrm{a}$ & $1.30 \mathrm{~ns}$ & $234.81 \mathrm{a}$ & $238.56 \mathrm{a}$ & $0.49 \mathrm{a}$ & $0.26 \mathrm{a}$ \\
\hline CV $(\%)$ & 20.15 & 13.65 & 11.07 & 18.34 & 46.06 & 45.72 & 16.78 \\
\hline Arrangement of cuttings (AC) & $46.72 * *$ & $5.53 \mathrm{~ns}$ & $107.55 * *$ & $1.21 \mathrm{~ns}$ & $20.03 * *$ & $0.81 \mathrm{~ns}$ & $5.93 \mathrm{~ns}$ \\
\hline Horizontal & $48.01 \mathrm{~b}$ & $39.83 \mathrm{a}$ & $1.09 \mathrm{~b}$ & $174.51 \mathrm{a}$ & $164.94 \mathrm{~b}$ & $0.46 \mathrm{a}$ & $0.28 \mathrm{a}$ \\
\hline Vertical & $61.46 \mathrm{a}$ & $44.73 \mathrm{a}$ & $1.42 \mathrm{a}$ & $181.91 \mathrm{a}$ & $226.52 \mathrm{a}$ & $0.48 \mathrm{a}$ & $0.24 \mathrm{a}$ \\
\hline $\mathrm{CV}(\%)$ & 14.39 & 16.69 & 10.16 & 15.10 & 28.12 & 21.89 & 27.13 \\
\hline IBA concentrations (IBA) & $1.10 \mathrm{~ns}$ & $5.22 * *$ & $9.14 * *$ & $5.38 * *$ & $6.08 * *$ & $3.22 *$ & $2.85 \mathrm{~ns}$ \\
\hline $\mathrm{CV}(\%)$ & 15.57 & 15.95 & 8.85 & 37.73 & 43.57 & 17.16 & 24.34 \\
\hline PCR X AC & $11.91 *$ & $9.45 *$ & $5.43 \mathrm{~ns}$ & $2.85 \mathrm{~ns}$ & $0.57 \mathrm{~ns}$ & $1.50 \mathrm{~ns}$ & $4.18 \mathrm{~ns}$ \\
\hline PCR X IBA & $1.10 \mathrm{~ns}$ & $0.17 \mathrm{~ns}$ & $0.43 \mathrm{~ns}$ & $0.65 \mathrm{~ns}$ & $0.13 \mathrm{~ns}$ & $4.02 *$ & $2.22 \mathrm{~ns}$ \\
\hline AC X IBA & $0.33 \mathrm{~ns}$ & $0.02 *$ & $3.77 *$ & $1.49 \mathrm{~ns}$ & $1.89 \mathrm{~ns}$ & $0.45 \mathrm{~ns}$ & $7.32 * *$ \\
\hline PCR X AC X IBA & $0.97 \mathrm{~ns}$ & $0.31 \mathrm{~ns}$ & $0.95 \mathrm{~ns}$ & $1.04 \mathrm{~ns}$ & $2.25 \mathrm{~ns}$ & $2.48 \mathrm{~ns}$ & $1.03 \mathrm{~ns}$ \\
\hline
\end{tabular}

$*$ and $* *=$ significant at the level of 5 and $1 \%$ probability. respectively; ns = not significant; $\mathrm{CV}=$ coefficient of variation; IBA = Indole-3-Butyric Acid 
For SC there was no statistical difference between the cuttings arrangement at 30 days. At 60 days, the vertical arrangement $(58.28 \%)$ stood out statistically in relation to the horizontal $(37.74 \%)$. When comparing the cuttings within the period of cutting in rooting, it was observed that horizontal arrangements were statistically superior to 30 days $(58.28 \%$ ) compared to the 60 days; the highest values were also observed for the vertical arrangements at 30 days $(64.94 \%)$, but did not differ from 60 days of cuttings $(57.99 \%)$ (Figure 2A).
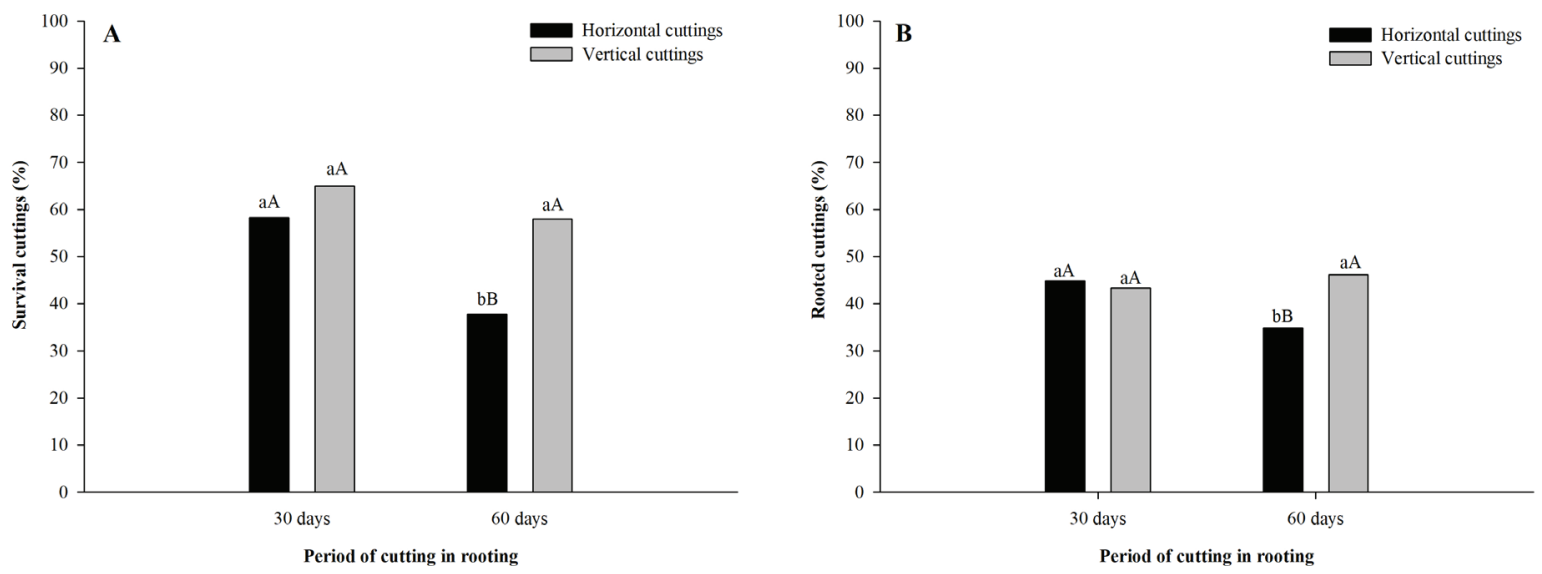

Figure 2. Survival cuttings (A) and percentage of rooted cuttings (B) of Rhaphiodon echinus Schauer in function of the period of cutting in rooting and arrangement of cuttings (horizontal and vertical). Capital letters compare the arrangement of cuttings between the days (30 and 60) and lowercase letters compare the period of cutting in rooting inside the days (30 or 60 ).

For the rooted cuttings, the same tendency was observed in the results. However, not all live cuttings presented root or beginnings of roots. The vertical arrangement (43.30\%) presented similar results to horizontal arrangements $(44.81 \%)$ at 30 days, but were higher at 60 days $(46.16 \%)$. Among the period of cutting in rooting, the horizontal arrangement (44.81\%) was significantly higher at 30 days, while vertically arranged cuttings were statistically similar between 30 and 60 days (Figure 2B).

The presence of leaves on the cuttings may have favored rooting and root formation. The leaves are sites for synthesis of auxin and carbohydrates and it is expected that the presence of the leaves on the cuttings favors the survival and the formation of roots. In addition, it is probable that the rooting and cuttings survival with leaves are related to the synthesis of phenolic compounds in the shoot (PACHECO and FRANCO, 2008). According to Hartmann et al. (2011), the potential of a stem to roots formation is very variable with the species, or even with the cultivar.

Considering the interaction of period of cutting in rooting and IBA concentrations for SDB, there was no difference between IBA concentrations for 30 days induction (Figure $3 \mathrm{~A}$ ), while at 60 days the data assumed sigmoidal behavior (Figure 3B). This demonstrates that application of IBA stood out from those which not received. Between the concentrations, the highest value for SDB (0.55 g) was obtained in $1000 \mathrm{ppm}$, and the successive increase of the concentrations caused a reduction in the dry mass of the shoot system. Probably levels above $1000 \mathrm{ppm}$ have become toxic, reducing root formation and consequently shoot growth. According to Taiz and Zeiger (2013), auxin is largely synthesized in the shoot system and transported towards the root, while the cytokinin is synthesized at the root and moves towards the shoot system. Thus, the high levels of auxin may have caused an inverse effect, reducing the emission of roots and consequently the shoot growth. In a study by Paulus et al. (2016), the results showed that exogenous application of IBA favors the accumulation of dry shoot mass (0.24 g) of Rosmarinus officinalis (rosemary) until the concentration of $2500 \mathrm{ppm}$. 

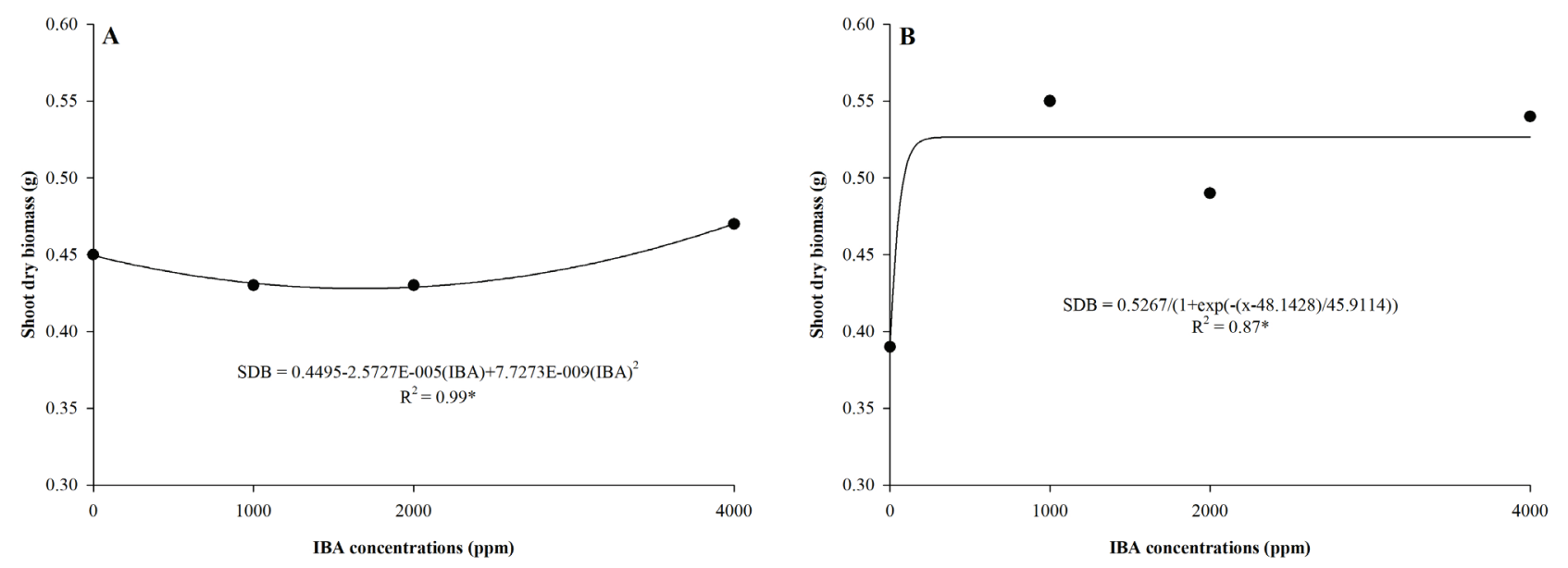

Figure 3. Shoot dry biomass of Rhaphiodon echinus Schauer at 30 days (A) and 60 days (B) of induction and IBA concentrations.

For the percentage of rooted cuttings due to the arrangement of cuttings and IBA concentrations, the both horizontal (Figure 4A) and vertical arrangement (Figure 4B) presented the same tendency with adjustment to the sigmoidal model. However, the cuttings in the vertical arrangement presented higher values than horizontal when the same concentration of IBA was applied. In general, the values for PRC were not high, but is noted the importance of the use of plant growth regulators for rooting, because in the absence of the application the PRC was below 40\%. The plant growth regulator can accelerate the normal metabolism and increase the number of beginnings roots, causing the emission of roots.
The amount of exogenous auxin for rooting stimulating or not depends on the species and the concentration of auxin present in the plant tissue (PAULUS et al., 2016). It was observed, for example, that IBA concentrations above 2,500 ppm caused a reduction in the rooting percentage of Rosmarinus officinalis cuttings (PAULUS et al., 2016) and also for Aloysia triphylla (limon) when IBA concentrations were above 1500 ppm (PAULUS et al., 2014). So, an adequate endogenous balance, especially between auxins, gibberellins and cytokinins, i.e. balance between promoters and inhibitors of the root initiation process is required for root emission in cuttings (TAIZ and ZEIGER, 2013). Considering this, the importance of studies with IBA concentrations is necessary to verify if a higher percentage can be obtained. 

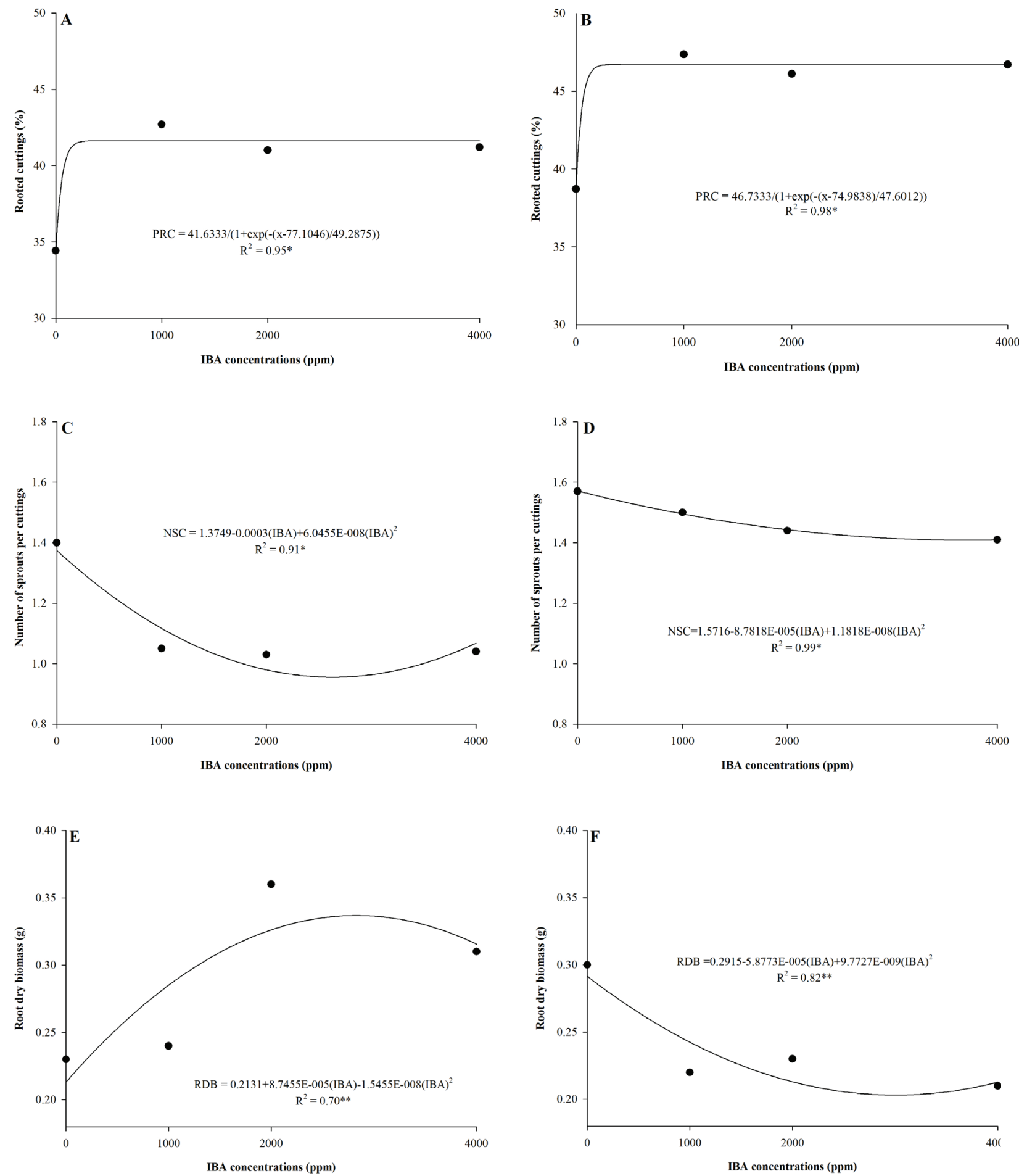

Figure 4. Horizontal and vertical arrangement of cuttings, respectively, for percentage of rooted cuttings (A and B), number of sprouts per cuttings (C and D) and root dry biomass ( $\mathrm{E}$ and $\mathrm{F}$ ) of Rhaphiodon echinus Schauer in different IBA concentrations. 
The NSC, both for the horizontal (Figure 4C) and vertical (Figure 4D) arrangement of cuttings showed a tendency to reduce the amount of sprouts for each IBA concentration used. It is observed that the non-application of IBA favored a better sprouting in cuttings, probably related to the more pronounced presence of cytokinins initially, and with increasing IBA applications, there was a reduction in the number of sprout per cuttings and, consequently, rooting occurred (FERREIRA and FERRARI, 2010; HARTMANN et al., 2011; TAIZ and ZAIGER, 2013). This fact can also be verified in camucamu (Myrciaria dubia H. B. K.), in which the application of IBA did not promote the emission of sprouts, but in its absence, allowed the highest number of sprout per cuttings (DELGADO and YUYAMA, 2010).

For RDB, it was observed that in the horizontal arrangement (Figure 4E) the increase in IBA concentrations promoted a distinct adjustment to that observed for vertical cuttings (Figure 4F). For horizontal and vertical arrangement of cuttings the major RDB obtained was 0.36 $\mathrm{g}$ and $0.30 \mathrm{~g}$ when $2,000 \mathrm{ppm}$ and no application of IBA were realized, respectively. With another species of the Lamiaceae family, Bona et al. (2010) observed that was no significant difference between IBA applications for dry root weight. Probably, this performance is related to the formation of the shoot system, coming from the sprouts. It was observed previously that cuttings in the horizontal arrangement presented opposite adjustment for the NSC (Figure 4C) when comparing to RDB, resulting from the competition between both parts (shoot system and root system) of the cutting, allowing more investment in root formation.

However, when analyzing the vertical arrangement both for NSC (Figure 4D) and RDB (Figure 4F) the adjustment is similar. It can be inferred that a balance has occurred between the formation of roots and the production of shoots per cutting. According to Hartmann et al. (2011) for seedlings quality should be have a balance between the shoot system and the root system, with a well-developed root system and no deformations.

Considering the isolated effect of the treatments for both the LLR and RV, it was observed that the period of cutting in rooting of 60 days was significantly higher in relation to 30 days. In the same way, the vertical arrangement of cuttings was superior to the horizontal ones (Table 1). Considering the concentrations of IBA, it was observed that for LLR (Figure 5A) and RV (Figure 5B) there was influence of concentration $1,000 \mathrm{ppm}$.
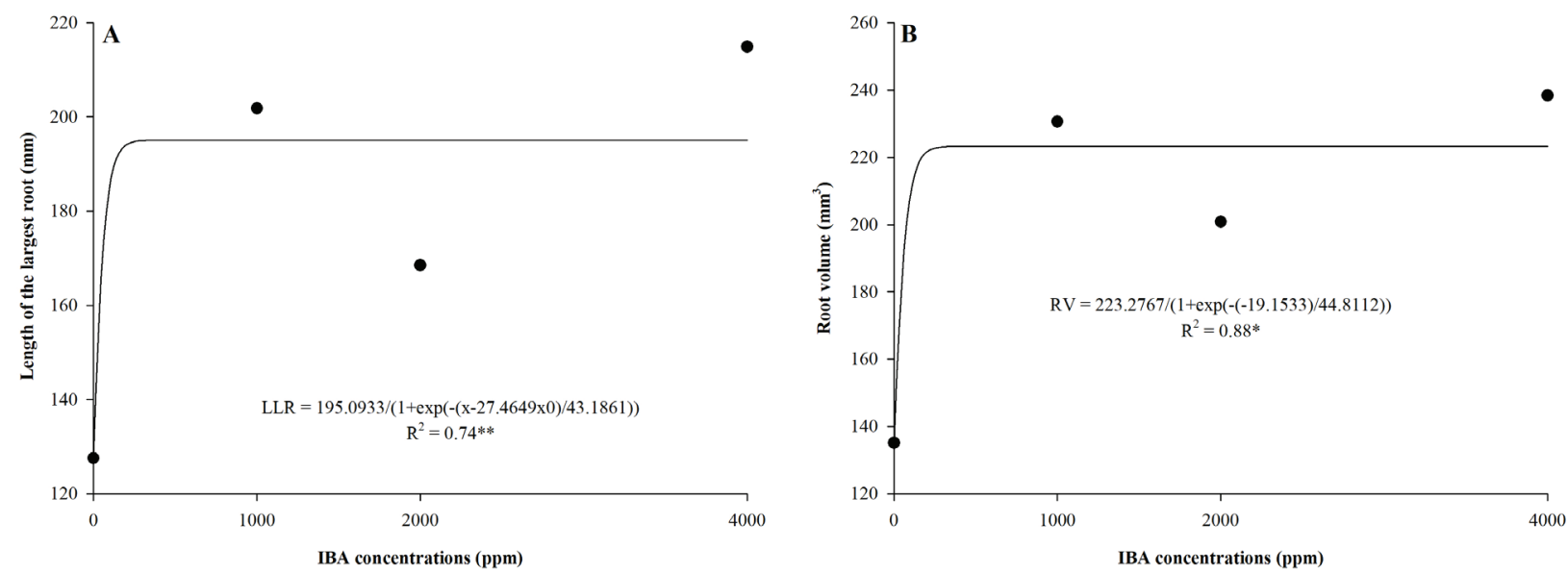

Figure 5. Length of the largest root (A) and root volume (B) of Rhaphiodon echinus Schauer cuttings under different IBA concentrations.

The application of auxin can provide a greater speed of formation and uniformity of the root system (HARTMANN et al., 2011; VIGNOLO et al., 2014). According to Moubayidin et al. (2010), the root growth occurs when in the apical meristem; cell division prevails over differentiation, a fact that occurs because there is a greater concentration of auxins promoting the division than cytokinins promoting differentiation and also, showed that the presence of leaves induced favorable balance of auxins.

Seedlings with a longer root length may have a better survival rate after transplantation compared to those with a lower root system; however, root volume is also important. In the first few weeks after transplanting, the conditions may be adverse and compromise survival, but on the other hand, the period of time the seedlings stay in the nursery also reflects their survival. The period of time between the formation of the seedling and its transfer to the field should be considered in order to avoid damage to the roots in the planting (breaking or folding) as well as to the shoot by the loss of leaves in the first days after planting (ZACCHEO et al., 2013; NAVROSKI et al., 2016).

\section{CONCLUSIONS}

Considering all the analyzed variables, the period of cutting in rooting of 30 days is the most appropriate for the rooting process of the cuttings, as well as the vertical arrangement of the cuttings provides better survival and rooting. In relation to IBA, the minimum concentration of $1,000 \mathrm{ppm}$ may be indicated for the production of $R$. 
echinus seedlings, but other studies should be carried out in order to increase the rooting percentage.

\section{ACKNOWLEDGMENTS}

The authors are thankful to the Coordination for the Improvement of Higher Education Personnel (CAPES), by the scholarship granted to the first author and to EMBRAPA (grant no. 02.14.01.005.00.00) to the financial support for conducting the experiment.

\section{AUTHORS CONTRIBUTION}

E.S.C.J.D0000-0003-3359-4944: Experimental conduction, analyzing the data and writing the manuscript. M.S.M.B. (D)000-0001-7407-3382: Assistance in experimental conduction. C.M.A.S. $10000-0002-2745-3267$ : Assistance in experimental conduction. R.C.S.S. (10000-0003-4217-8571: Assistancein experimental conduction. L.H.P.K. (10000-0003-0307-9634: Coordination, assistance in conducting the experiment and writing the manuscript. M.Z.B.C. D0000-0002-2594-1769: Experimental planning and assistance in the interpretation of results.

\section{REFERENCES}

ALVARES, C.A.; STAPE, J.L.; SENTELHAS, P.C.; GONÇALVES, J.L.M.; SPAROVEK, G. Köppen's climate classification map for Brazil. Meteorologische Zeitschrift, v.22, p.711-728, 2014. DOI: 10.1127/09412948/2013/0507

AMARAL, G.C.; BRITO, L.P.S.; AVELINO, R.C.; SILVA JÚNIOR, J.V.; BECKMANN-CAVALCANTE, M.Z.; CAVALCANTE, Í.H.L. Produção de mudas de Duranta repens $\mathrm{L}$. pelo processo de estaquia. Revista de Ciências Agrárias, v.35, n.1, p.134-142, 2012.

BECKMANN-CAVALCANTE, M.Z.; AMARAL, G.C.; AVELINO, R.C.; BRITO, L.P.S.; CAVALCANTE, I.H.L. Propagação de Alternanthera dentata pelo processo de estaquia. Comunicata Scientiae, v.5, n.2, p.170-177, 2014.

BECKMANN-CAVALCANTE, M.Z.; DULTRA, D.F.S.; SILVA, H.L.C.; COTTING, J.C.; SILVA, S.D.P.; SIQUEIRA FILHO, J.A. Potencial ornamental de espécies do Bioma Caatinga. Comunicata Scientiae, v.8, n.1, p.4358, 2017a. DOI: https://doi.org/10.14295/cs.v8i1.2649

BECKMANN-CAVALCANTE, M.Z.; SABINO, J.H.F.; BARBOSA, M.S.M.; DULTRA, D.F.S.; SILVA, H.L.C.; SILVA, S.D.P.; STUMPF, E.R.T. Innovation in floriculture with ornamental plants from Caatinga biome. Ornamental Horticulture, v.23, n.3, p.289-295, 2017b. DOI: http:// dx.doi.org/10.14295/oh.v23i3.1081
BONA, C.M.; BIASI, L.A.; LIPSKI, B.; MASETTO, M.A.M.; DESCHAMPS, C. Adventitious rooting of auxintreated Lavandula dentata cuttings. Ciência Rural, v.40, n.5, p.1210-1213, 2010. DOI: http://dx.doi.org/10.1590/ S0103-84782010005000081

CARDOSO, J.C. Melhoramento de espécies ornamentais como estratégia para o desenvolvimento e autossuficiência do setor. Horticultura Brasileira, v.31, n.1, 2013. DOI: http://dx.doi.org/10.1590/S0102-05362013000100028

DELGADO, J.P.M.; YUYAMA, K. Comprimento de estaca de camu-camu com ácido indolbutírico para a formação de mudas. Revista Brasileira de Fruticultura, v.32, n.2, p.522-526, 2010. DOI: http://dx.doi.org/10.1590/S010029452010005000066

DIAS, J.P.T.; TAKAHASHI, K.; FILHO, J.D.; ONO, E.O. Enraizamento de estacas de brotações oriundas de estacas radiculares de amoreira-preta. Revista Brasileira de Fruticultura, v.33, n.1, p.649-653, 2011. DOI: 10.1590/ S0100 29452011000500090

DRAGOVIC, M.J.O. Selection and domestication of endemic species from macaronesia with ornamental value. Acta Horticulturae, v.1097, p.193-198, 2015. DOI: http://dx.doi.org/10.17660/ActaHortic.2015.1097.23

FERREIRA, G.; FERRARI, T.B. Enraizamento de estacas de atemoieira (Annona Cherimola Mill. X A. squamosa L.) cv. Gefner submetidas a tratamento lento e rápido com auxinas. Ciência e Agrotecnologia, v.34, n.2, p.329-336, 2010. DOI: http://dx.doi.org/10.1590/S141370542010000200009

FERREIRA, P.V. Estatística experimental aplicada à Agronomia. Maceió: EDUFAL, 2000. 604 p.

FORZZA, R.C.; BAUMGRATZ, J.F.A.; BICUDO, C.E.M.; CANHOS, D.A.L.; CARVALHO JR. A.A.; COELHO, M.A.N.; COSTA, A.F.; COSTA, D.P.; HOPKINS, M.G.; LEITMAN, P.M.; LOHMANN, L.G.; LUGHADHA, E.N.; MAIA, L.C.; MARTINELLI, G.; MENEZES, M.; MORIM, M.P.; PEIXOTO, A.L.; PIRANI, J.R.; PRADO, J.; QUEIROZ, L.P.; SOUZA, S.; SOUZA, V.C.; STEHMANN, J.R.; SYLVESTRE, L.S.; WALTER, B.M.; ZAPPI, D.C. New Brazilian floristic list highlights conservation challenges. BioScience, v.62, n.1, p.39-45, 2012. DOI: http://dx.doi.org/10.1525/bio.2012.62.1.8

HARTMANN, H.T.; KESTER, D.E.; DAVIES, R.T.; GENEVE, R.L. Plant propagation: principles and practices. 8 ed. New Jersey: Prentice Hall, 2011. 915p. 
KIRCHHOF, G.; PENDAR, K. Delta-T SCAN User Manual. Cambridge: Delta-T Scan Devices Ltd, 1993. $244 p$.

MOREIRA, H.J.C.; BRAGANÇA, B.N. Manual de identificação de plantas infestantes: hortifrúti. São Paulo: FMC Agricultural Products, 2011. 1017p.

MOUBAYIDIN, L.; PERILLI, S.; LOIO, R.D.; MAMBRO, R.; COSTANTINO, P.; SABATINI, S. The rate of cell differentiation controls the Arabidopsis root meristem growth phase. Current Biology, v.20, n.12, p.1138-1143, 2010. DOI: $10.1016 /$ j.cub.2010.05.035

NAVROSKI, M.C.; TONETT, E.L.; MAZZO, M.V.; FRIGOTTO, T.; PEREIRA, M.O.; GALVANI, L.V. Procedência e adubação no crescimento inicial de mudas de cedro. Pesquisa Florestal Brasileira, v.36, n.85, p.17-24, 2016. DOI: DOI: https://doi.org/10.4336/2016. pfb.36.85.966

NEVES, T.S.; CARPANEZZI, A.A.; ZUFFELLATORIBAS, K.C.; MARENCO, R.A. Enraizamento de corticeira-da-serra em função do tipo de estaca e variações sazonais. Pesquisa Agropecuária Brasileira, v.41, n.12, p.1699-1705, 2006.

OINAM, G.; YEUNG, E.; KUREPIN, L.; HASLAM, T.; VILLALOBOS, A.L. Adventitious root formation in ornamental plants: I. general overview and recent successes. Propagation of Ornamental Plants, v.11, n.2, p.78-90, 2011.

PACHECO, J.P.; FRANCO, E.T.H. Substratos e estacas com e sem folhas no enraizamento de Luehea divaricata Mart. Ciência Rural, v.38, n.7, p.1900-1906, 2008. DOI: 10.1590/S0103-84782008000700015

PAULUS, D.; VALMORBIDA, R.; PAULUS, E. Ácido indolbutírico na propagação vegetativa de alecrim. Horticultura Brasileira v.34, n.4, p.520-528, 2016. DOI: http://dx.doi.org/10.1590/s0102-053620160411
PAULUS, D.; VALMORBIDA, R.; TOFFOLI, E.; PAULUS, E. Propagação vegetativa de Aloysia triphylla (L'Hér.) Britton de acordo com IBA e comprimento de estacas. Revista Brasileira de Plantas Medicinais, v.16, n.1, p.25-31, 2014. DOI: http://dx.doi.org/10.1590/ S1516 05722014000100004

SILVA, F.A.S. Assistat Versão 7.7 beta. Campina Grande: DEAG-CTRN-UFCG. 2016. (Registro INPI 0004051-2).

SIQUEIRA FILHO, J.A. A Flora das Caatingas do Rio São Francisco: história natural e conservação. Rio de Janeiro: Editora Andrea Jakobsson, 2012. 552 p.

STUMPF, E.R.T.; ROMANO, C.M.; BARBIERI, R.L.; HEIDEN, G.; FISCHER, S.Z.; CORRÊA, L.B. Características ornamentais de plantas do Bioma Pampa. Revista Brasileira de Horticultura Ornamental, v.15, n.1, p.49-62, 2009.

SYSTAT SOFTWARE Inc. SigmaPlot for windows, version 12. 2011.

TAIZ, L.; ZEIGER, E. Fisiologia vegetal. 5ed. Porto Alegre: Artmed, 2013. 954p.

VIGNOLO, G.K.; PICOLOTTO, L.; GONÇALVES, M.A.; PEREIRA, I.S.; ANTUNES, L.E.C. Presença de folhas no enraizamento de estacas de amoreira-preta. Ciência Rural, v.44, n.3, 2014.

ZACCHEO, P.V.C.; AGUIAR, R.S.; STENZEL, N.M.C.; NEVES, C.S.V.J. Tamanho de recipientes e tempo de formação de mudas no desenvolvimento e produção de maracujazeiro-amarelo. Revista Brasileira de Fruticultura, v.35, n.2, p.603-607, 2013. DOI: http:// dx.doi.org/10.1590/S0100-29452013000200032 